\title{
Alta incidência de Pepper yellow mosaic virus em tomateiro em região produtora no Distrito Federal
}

\author{
Érico C. Dianese ${ }^{1}$, Renato O. Resende ${ }^{1}$ \& Alice K. Inoue-Nagata ${ }^{2}$ \\ ${ }^{1}$ Departamento de Fitopatologia, Universidade de Brasília, 70910-900, Brasília, DF, Brasil; ${ }^{2}$ Embrapa Hortaliças, Cx. Postal 218, \\ 70359-970, Brasília, DF, Brasil
}

Autor para correspondência: Alice K. Inoue-Nagata, e-mail: alicenag@cnph.embrapa.br

\begin{abstract}
RESUMO
Várias doenças ameaçam a produção de tomate, especialmente aquelas causadas por vírus dos gêneros Begomovirus, Tospovirus e Potyvirus. Uma análise de amostras foliares de tomateiro para detecção dos vírus de maior importância no Distrito Federal foi realizada utilizando-se as técnicas de PCR e DAS-ELISA. Em um total de 54 amostras avaliadas, o vírus mais prevalente foi o Pepper yellow mosaic virus, um potyvírus responsável por sérias perdas em áreas de produção de pimentão no Brasil. Este resultado reforça a crescente importância deste vírus na produção de tomate. Os sintomas causados por PepYMV são muito similares àqueles causados por begomovírus, portanto é recomendada que uma técnica de detecção apropriada seja utilizada em adição à avaliação visual de sintomas.

Palavras chave: Solanum lycopersicum, hortaliças, diagnose.
\end{abstract}

\begin{abstract}
High incidence of Pepper yellow mosaic virus in tomatoes in productive areas of Brazil's Federal District

Various diseases threaten tomato production; especially those caused by viruses of the genera Begomovirus, Tospovirus and Potyvirus. A survey on the major viral diseases occurring on tomatoes in the Federal District was carried out using PCR and DAS-ELISA. Out of 54 evaluated samples, the most prevalent virus was Pepper yellow mosaic virus, a potyvirus responsible for heavy losses in sweetpepper production in Brazil. This result highlights the increasing importance of this virus on the tomato crop. Since the symptoms caused by PepYMV infection are similar to those caused by begomoviruses, the use of a proper detection technique is recommended in addition to visual evaluation of symptoms.
\end{abstract}

Keywords: Solanum lycopersicum, vegetables, diagnosis.

O tomate (Solanum lycopersicum) é uma hortaliça de grande importância no mundo, sendo afetada por diversas doenças causadas por vírus (tospovírus, begomovírus, tobamovírus e potyvírus). Este trabalho teve por objetivo realizar um estudo dos principais vírus que infectam o tomateiro em um dos principais pólos produtores de olerícolas do Distrito Federal, a região de Taquara. Este núcleo rural apresentou em 2006 a maior área dedicada ao cultivo de hortaliças da região com 697,82 hectares, o que corresponde a $24,8 \%$ da área plantada com hortaliças do Distrito Federal (Emater, 2006). A produção de tomate foi de 2.674 toneladas, em uma área de aproximadamente 34 hectares.

Em agosto de 2005, dois campos de produção foram visitados com tomateiros de 30-40 dias (campo 1) e de 80-90 dias (campo 2), com vários híbridos e materiais de polinização aberta. As coletas foram realizadas de maneira tendenciosa, buscando-se plantas de tomate com sintomas de mosaico, clorose, bolhosidade ou amarelecimento (Figura 1). Apenas dois produtores foram visitados, devido à contiguidade das áreas de produção e do provável compartilhamento dos principais patógenos presentes nas lavouras. As 54 amostras foliares coletadas foram analisadas pela técnica de PCR para detecção de begomovírus utilizando os primers pALv1978 e pARc496 (Rojas et al., 1993) e ELISA para o cucumovírus Cucumber mosaic virus (CMV), os potyvírus Potato virus $Y$ (PVY) e Pepper yellow mosaic virus (PepYMV) e os tospovírus Tomato spotted wilt virus (TSWV), Tomato chlorotic spot virus (TCSV), Groundnut ringspot virus (GRSV) e Chrysanthemum stem necrosis virus (CSNV). As análises foram realizadas no Laboratório de Virologia e de Biologia Molecular da Embrapa Hortaliças.

Das 30 amostras coletadas no campo 1, todas apresentaram infecção por isolados de PepYMV, confirmado pela técnica de DAS-ELISA. Nenhuma delas estava infectada com begomovírus. No campo 2 foram coletadas 24 amostras, sendo que 16 foram positivas para infecção por PepYMV e 18 por begomovírus. Onze amostras analisadas do campo 2 apresentaram infecção mista por PepYMV e begomovírus. Foi detectada a presença de PVY em quatro amostras, de CMV em duas amostras e de TSWV em uma amostra. Os vírus TCSV, GRSV e CSNV não foram detectados.

A alta incidência de PepYMV demonstra o aumento da incidência deste vírus em tomateiro. Os 


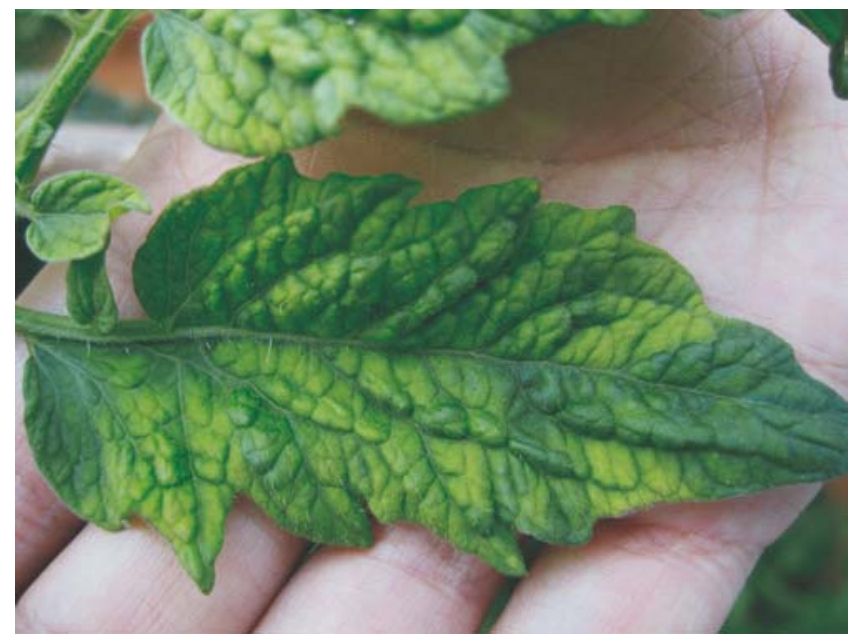

FIG. 1 - Tomateiro infectado com Pepper yellow mosaic virus apresentando sintoma de mosaico.

materiais comerciais de tomate utilizados atualmente são, aparentemente, todos suscetíveis a PepYMV. O potencial de danos para à produção de tomate causada por isolados de PepYMV, conforme relatado em regiões produtoras do Espírito Santo, é alto (de Ávila et al., 2004; MacielZambolim et al., 2003). Acredita-se que os isolados de PepYMV estejam ocupando o nicho que antigamente era ocupado pelos isolados de PVY, vírus que era responsável por perdas importantes em culturas de tomateiro. A partir da introdução de variedades resistentes (Lourenção et al., 2005), o PVY teve sua importância diminuída, dando lugar ao novo potyvírus identificado em 2002 infectando pimentões e pimentas (Inoue-Nagata et al., 2002). Os testes realizados em amostras coletadas nesta região durante os últimos anos demonstram uma alta incidência dos begomovírus em tomateiro (Fernandes et $a l .$, no prelo). Acredita-se que a inexistência de amostras infectadas com begomovírus no campo 1 foi devido ao estádio ainda precoce da cultura e à ausência da moscabranca nesta lavoura. Já no campo 2, com plantas mais velhas, a incidência de begomovírus foi elevada. O número de amostras coletadas foi pequeno, mas a alta porcentagem de plantas infectadas com isolados de PepYMV, um vírus com grande potencial de dano à cultura do tomate, reforça a necessidade de medidas de controle visando, preferencialmente, à resistência a esse patógeno. Os sintomas causados por PepYMV e os causados por begomovírus muitas vezes se confundem. Ressaltase também que a identificação de infecções mistas em diversas amostras de campo indica que a interação (sinergismo/antagonismo) entre espécies virais pode constituir-se em um fator complicador na diagnose desses patógenos. Assim, a análise de sintomas não pode ser utilizada para diagnose de modo confiável, sendo necessária a utilização de métodos mais precisos de detecção viral para monitoramento dos campos de cultivo de tomateiro.

\section{REFERÊNCIAS BIBLIOGRÁFICAS}

de Ávila AC, Inoue-Nagata AK, Costa H, Boiteux LS, Neves LOQ, Prates RS, Bertini LA (2004) Ocorrência de viroses em tomate e pimentão na região serrana do estado do Espírito Santo. Horticultura Brasileira 22:655-658.

Fernandes FR, Albuquerque LC, Giordano LB, Boiteux LS, de Ávila AC, Inoue-Nagata AK (2008) Diversity and prevalence of Brazilian bipartite begomomovirus species associated to tomatoes. Virus Genes 36:251-258.

Inoue-Nagata AK, Fonseca MEN, Resende RO, Boiteux LS, Monte DC, Dusi AN, de Ávila AC, van der Vlugt RAA (2002) Pepper yellow mosaic virus, a new potyvirus in sweetpepper, Capsicum annuит. Archives of Virology 147:849-855.

Lourenção AL, Siqueira WJ, Melo AMT, Palazzo SRL, Melo PCT, Colariccio A (2005) Resistência de cultivares e linhagens de tomateiro a Tomato chlorotic spot virus e a Potato virus $Y$. Fitopatologia Brasileira 30:609-614.

Maciel-Zambolim E, Costa H, Capucho AS, de Ávila AC, InoueNagata AK, Kitajima EW (2003) Surto epidemiológico do vírus do mosaico amarelo do pimentão em tomateiro na região serrana do Espírito Santo. Fitopatologia Brasileira 29:325-327.

Rojas MR, Gilbertson RL, Maxwell DP (1993) Use of degenerate primers in the polymerase chain reaction to detect whiteflytransmitted geminiviruses. Plant Disease 77:340-347.

Recebido 27 Agosto 2007 - Aceito 12 Fevereiro 2008 - TPP 7095 Editor Associado: F. Murilo Zerbini 